\title{
The Alteration in Jamba and Pinumkopi on Prophet Muhammad SAW Maulid Ceremony in Pariaman - Indonesia
}

\author{
Jupriani, Mukhaiyar, Agusti Efi
}

\begin{abstract}
The birthday of the Prophet Muhammad SAW is one of the religious and cultural ceremonies carried out by the people of West Sumatra, precisely in Padang Pariaman. The MaulidPariaman ceremony is performed in a unique tradition by using cultural attributes that are only found in that area. This Maulid ritual is usually performed exactly in the months of Rabiul Awal, Rabiul Akhir, and Jumadil Awal (Arabic Calendar) or Mauluik, Adiakmauluik, Adiak MauluikK aduo (Pariaman Calendar). This research is a qualitative study using interview data as informants. Data processing uses descriptive qualitative data analysis techniques. The results of this study found that there are changes in the jamba and pinumkopi performed at Pariaman. A very revolutionary change occurred in jamba and pinumkopi. The alteration occurs in a modern way. The conclusion of this study shows that the changes that occur in jamba and pinumkopi in Pariaman do not change function and meaning. However, Change occurs because there is social change.

Keywords: alteration, culture, ceremony, mauled, Pariaman
\end{abstract}

\section{INTRODUCTION}

$\mathrm{M}$ aulid of the Prophet Muhammad SAW for people of Pariaman is a major event of celebration spread across the range of 3 months which is recognized as the moon muluik , $a$ diak muluik and adiak muluik ka duo . (Interview: Labai Safar 2020). For the community of Pariaman, the commemoration of maulid is an implication for religious teachings that require humans to develop a relationship with God (hablumminallah) and with fellow humans (hablumminannas). The Prophet's birthday is a package of offerings to Allah as an expression of gratitude to the human creator and the feeling of happiness over the sending of the beloved prophet of Allah SWT to improve human morals (Interview: Buya Syofyan 2020). Every effort is made to make the sacredness of this maulid celebration carried out with great fanfare.

Pariaman uniquely commemorates the maulid event, namely by holding a ceremony with various completeness,

Manuscript received on February 17, 2021.

Revised Manuscript received on March 30, 2021.

Manuscript published on March 30, 2021.

* Correspondence Author

Jupriani*, Doctoral Student of Education Sciences, and Lecturer of Department of Fine Arts, Universitas Negeri Padang - Indonesia. Email: jupriani.jupriani@gmail.com

Mukhaiyar, Senior lecturers/professors of Education Sciences, Universitas Negeri Padang - Indonesia. Email: mukhaiyar@fbs.unp.ac.id

Agusti Efi, Senior lecturers/professors of Education Sciences, Universitas Negeri Padang - Indonesia. Email: agustiefi@gmail.com

(C) The Authors. Published by Blue Eyes Intelligence Engineering and Sciences Publication (BEIESP). This is an open access article under the CC BY-NC-ND license (http://creativecommons.org/licenses/by-nc-nd/4.0/) for example, serve by complete food and long religious rituals. The food served at the maulid commemoration event is not ordinary but is food that is specially prepared from the produce of the garden itself, with side dishes from own livestock or from the environment itself that have been prepared from a long time ago (Jumadil Awal or after adiak muluik kaduo) until at the coming of the next maulid event.

Pinumkopi is a food accompaniment or snack which is also served at maulid events. This dish is a snack when the public is listening to badikie, bersalawat dulang or with the berzanjit hat is always displayed in the mauled event.

Jamba and pinumkopi are usually made with the hands of a nephew, now they can't be seen anymore. According to Andeh Rasima interview in 2020, One Siah, Andeh Nia, once the cooking tradition is a place pangaja (Learning) to children nephew in practising persistence, sensitivity taste, solidarity, mutual respect, saving behaviour, etc through the cooking with the culinary variety typical of society inPariaman. Likewise, Pinumkopi, which used to be the traditional food of Pariaman, consists of all foods that do not cause thirst, such as lapek sagan, lapek ubi, lapek bugi, lapek pisang, lapek bareh and local fruits such as oranges, duku, banana, sugar cane (interview with Uo Rahima, 2020) now it has been very drastic, the changes are now replaced with snacks, cakes, candy, Sunkist, apples, etc. which are delivered to the mosque in a very striking container called a display (Pajangan).

Currently, there have been alterations to jamba and pinumkopi. Cultural and technological developments and issues brought about by globalization bring changes in the mindset of the people. Many traditional things are no longer favoured by the community. Moreover, the system of cultural inheritance which is only done by inheritance behaviour and outward form (visual) without inheritance values that contained in the object of the culture. Traditional inheritance is effective if one community group stays, and has daily activities with the community. But if the next generation is only present temporarily in one community, they will not have time to understand the values implied behind every cultural activity or cultural artefact [1].

\section{RESEARCH METHODS}

This research is qualitative research, to understand the phenomenon and describe the Prophet Muhammad's birthday from the perspective of participants [2]. Data were collected through observation and in-depth interviews. The research instrument consisted of observation sheets and interview guides that had been prepared previously [3]. 
The interview begins with interviewing religious and cultural figures to make it easier for researchers to communicate with other informants.

These informants are what researchers use as key informants [4].

The informants developed with engineering snowballing(snowball), where an informant recommend another informant thought to have information equivalent or greater [2]. After the observations and interviews were carried out, at the end of the research activity, a Focus Group Discussion (FGD) was carried out, inviting traditional leaders, great scholars, community leaders, the head of the Dharmawanita (bundo kanduang) and youth. FGDs were conducted to verify the data that had been obtained and also to obtain additional data that might have been missed in the data collection process that was already underway. Data processing uses descriptive qualitative data analysis techniques [5]. This technique is carried out by classifying the data collected, arranged, and explained using sentences that are separated by category to get a conclusion.

\section{FRAMEWORK}

In society, there are unique ways that become a medium for the inheritance of cultural values that live in the community, such as through informal education in the family and through interactions with the environment. In essence, social activities can be interpreted as a system of behaviour that reflects the values of community life. Maulid prophet Muhammad was organized by a set of rules based on the culture of Pariaman which has five elements of the social, the family, religion, education, and economics. Education informally also a social organization that serves as the implementing and enculturation, to deliver the right people Pariaman in social life and culture. Maulid is said to be customary inheritance because the Prophet's birthday is an activity to meet the social and religious needs of the community in the context of the inheritance of customs and cultural values from one generation to the next. According to [6], the relevance between education and cultural transformation is, first, that education is an agent of convention and tradition that works to ensure the same truth is shared with the next generations. Second, education is an agent of change and advocacy for innovation. These cultural values are also often mentioned as customary behaviour, which means that cultural values usually also function as behaviours that regulate, control, and give direction to human behaviour and actions in society [4]. Cultural value is an important evaluative symbol in social life.

The disharmony of relationships that exist in society is of course rooted in the conditions of existing cultural values [7]. One of the ways to do informal education in the family and community is through social activities such as religious activities and traditional activities as an effort to strengthen the values contained in society. The values received by individuals from previous generations through customary activities will in time shape the character of the younger generation.

Characters are typical values or good values (interpreting goodness, the desire to do good, good behaviour, which has a good impact on the environment) which have become internalized in individuals and are implied in behaviour. Kindness values are born from the results of thinking, cultivating the heart, cultivating the soil, and cultivating the feelings and intentions of a person or group of people that contain values, abilities, moral capacities, and toughness in facing difficulties and challenges. Thus, informal education through religious and customary activities plays an important role in cultural transmission from generation to generation. According to [8], socio-cultural transmission to the next generation is very important in cultural preservation. Still, according to Kroeber, culture includes activities that are conditioned or studied (complete with the results they produce); and the idea of learning brings back again to things that are passed on socially, things that are received from tradition, things that one gets as a member of society. Without a social transmission, a culture will disappear by itself [9]. [6] states that various skills in a tradition related to the formation of values, actually lead to one achievement in individual life, namely the formation of habits, namely the result of skills that become practical behaviour (not necessarily aware of), they become a natural and develop in a particular social environment. The educational value should it take into account the way how it can be formed habitus, whether through training, habituation, experience, and observation.

The scope of activities of religious beliefs and customs allows the entire mechanism of spiritual, perception, and evaluation of a person to open up and train themselves in social relations, assimilating the norms and values of a society, became him as the basis of personality. Habitus that emphasizes the problem of values and norms forms an ethos, namely principles or values that are practised, or a form of internalized moral that does not appear in awareness, but is effective in regulating daily behaviour. For example, honest, hardworking, nimble, open-minded and tolerant [10]. The results of value education through religious education that are integrated with tradition direct the community to form their habitus.

\section{DISCUSSIONS}

Currently the maulid ceremony is still carried out in the same way. Jamba and pinumkopi also still exist. However, the shapes and objects used are different. Socially there is no difference as well as meaning. This is normal, social change and cultural change do not always occur together, social change is a change in terms of social structure and social relations, while cultural change includes changes in the cultural aspects of society [11], translation of [12]. The development of science and the alternation of generations brings changes to society. Likewise with jamba and pinumkopi. Based on the results of the observations, it is found that there has been a change in Jamba. The change is that there are preparations. When the jamba preparation activities are carried out only by parents and children because their grand children as the next generation no longer live at home because they are studying in the city, usually the children (grandchildren) work to help their parents and grandmothers to peel onions, grind the spices, clean the ingredients to be used etc.

In the case of the Jamba menu, there have also been changes. Initially,

Published By:

Blue Eyes Intelligence Engineering DOI:10.35940/ijmh.F1243.035721

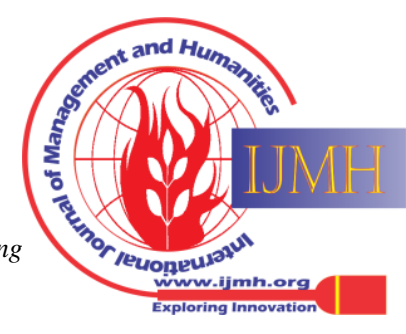


it consisted of the results of the natural wealth itself, such as tuna/scales, long beans, round eggplant, petai, salted fish, and boiled egg. What interesting is that the fish used is a whole fish whose length is between $30-40 \mathrm{~cm}$ made sour and spicy or fried. Because the fish is large, the cooking process has to be cut in half and then when served the fish is reattached as if it would be whole. So that the fish connection does not appear to be visible, coat it with thick chilli sauce or fried chillies (dibadak-i). One thing that is interesting at this time is that the fish is covered with soy sauce, given fried noodles and some are given mayonnaise.

These changes are mostly brought about by the younger generation who come from environments that have assimilated a lot to a heterogeneous environment. According to One Siah, this change has indeed occurred in the last 5-7 years. According to her, this change has been seen by many people outside Pariaman to decorate the fish in such a way that the appearance was imitated and implied on the jambamaulud. According to Uni Mawar, "kiniko baa nan kaancak, baa nan kaelok je nyeh". It means that they are no longer pay attention to that value, but they are more pay attention to the shape and look. From the answer given by One Siah, Uni Mawar feels bitter and compelled to accept the change.

These changes are the impact of social changes, changes in science make changes in people's mindsets. Alternation of generations and changing tastes also drive change. [13] said, every society is always changing. Social changes that occur can change social values, social norms, behaviour patterns, social institutional arrangements, layers in society, power and authority, social interactions, etc. Furthermore, according to SeloSoemarjan in [14] adds between changes social and cultural change have one aspect in common, namely that they both relate to an acceptance of new methods or an improvement in the way people meet their needs. From this opinion, it is known that change is a natural thing because social change always goes hand in hand with cultural change.

The existence of social and cultural changes in the community also causes changes in the customs and traditions of their respective territories or changes in the mindset of the community so that people do not think about what habits they have carried out from the past. According to [15], social change is a process in people's life that occurs gradually which affects attitudes from time to time. Modernization greatly affects the life lived by humans, besides modernization also results in various kinds of social changes that occur in society, the social changes that are experienced are caused to maintain balance in society, changes that occur in the modernization era, such as changes in geographical, biological, and economic elements as well as culture.
According to [16] social change is caused by increasing and decreasing population, discoveries, opposition from society and cultural influences from other communities. Furthermore, [17] describes discoveries where major social and cultural processes are occurring, such as the entry of new cultures in society and then accepted, studied, and over time will be used in that community. Communities are forced to/have to accept these changes, conflicts between the older generation and the younger generation will often occur in societies that are developing from the traditional stage to the modern stage.

The most revolutionary change occurred in pinumcopy. Drinking coffee that was previously made with "kakok tangan kemenakan" has now changed drastically. All of them use fast food. Fast with all its kinds and bananas and sugar cane are no longer available, it replaced by snacks, nuts, and various types of bread, as well as canned drinks such as coca-cola, sprite, milo, the glass, pocari sweat etc. The fruits have also changed, now maulid uses apple, peer, Sunkist, watermelon. All these modern meals are also delivered to the maulid venue with a modern container called pajangan. Displays of the cake were generated in 98 small food plates, and ornamental pieces also are delivered with a display full of knickknacks made tiles. This is also caused by changing mindsets caused by social changes. Modernization that touches all levels of human civilization, in the Pariaman society, is gradually being able to erode the customary values at the birthday ceremony of the prophet Muhammad SAW. The initiators of this change were also sanctioned by some scholars and they made justification by saying this was all made to celebrate the birthday of the prophet and was applied by delivering as much jamba and pinumkopi as possible.

This is where there is a conflict between the concepts of the maulid warning which was initiated by SyekhBurhanudin who taught to remember the maulid simply. Then also in the custom of Pariaman according to Buya Syofyan, the food that is brought to the mosque for the maulid is sufficient. "makanan dibaok sajujuangan, paliang sangenek 5 piriang, paliang banyak 17 piriang". However, social change says differently, this change happened so massively and generally accepted by Pariaman people. In the case of Pariaman custom, it is stated that "syarak mangato, adat mamakai" is no longer practiced in jamba and pinumkopi that are used in maulid events. Because all the food that is brought is also not consumed and ends up being redundant. In the customary adage, it is also said that "manambah ancak-ancak, mangurangi sio-sio" meaning that if you add it, it should be according to the ideal measure, but if you reduce it, do not damage the existing order in society. Some of these changes can be seen in the following Table 1 below:

Table- I: The difference between old and new food in jamba and pinumkopi is used in the maulid event

\begin{tabular}{|c|c|c|c|c|}
\hline Traditional Food & Fruits & Decorative Cake & Instant Snacks & Fruits \\
\hline $\begin{array}{l}\text { Types of cakes: (Godok Batinta, } \\
\text { Godok Pisang, Godok Ubi, Lapek } \\
\text { Pisang, Lapek Bugih, Lapek } \\
\text { Garen, Lapek Koci, Lapek Sagan } \\
\text { and Onde-Onde) }\end{array}$ & $\begin{array}{l}\text { Local Harvest Results of the } \\
\text { Pariaman Community and } \\
\text { Local Wisdom (Banana and } \\
\text { Sugarcane) }\end{array}$ & $\begin{array}{l}\text { Buy finished or Order } \\
\text { (Chocolate sponge cake, } \\
\text { brownies, chocolate cake, } \\
\text { banana cake and others) }\end{array}$ & $\begin{array}{c}\text { Factory-made modern snacks ( Better, } \\
\text { Garuda Rosta, Choco Cheese, GDR } \\
\text { Beans, Fried Noodles, Wafello, } \\
\text { Nextar, Kiss Candy, and Milkita) }\end{array}$ & $\begin{array}{l}\text { Local and Import } \\
\text { (Apples, Salak, Sunkist, } \\
\text { Pears, Rambutan and } \\
\text { Duku) }\end{array}$ \\
\hline \multicolumn{5}{|c|}{ Made by “AnakKemanakan" } \\
\hline \multicolumn{5}{|c|}{ The results of local wisdom } \\
\hline \multicolumn{5}{|c|}{ Raw materials from the local harvest } \\
\hline
\end{tabular}

Published By:

Blue Eyes Intelligence Engineering and Sciences Publication

103 (c) Copyright: All rights reserved.

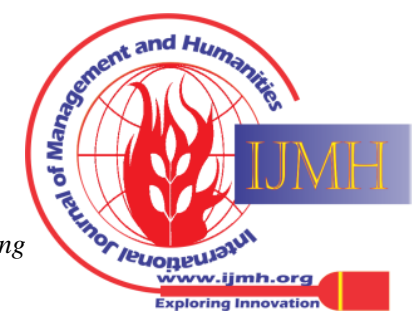




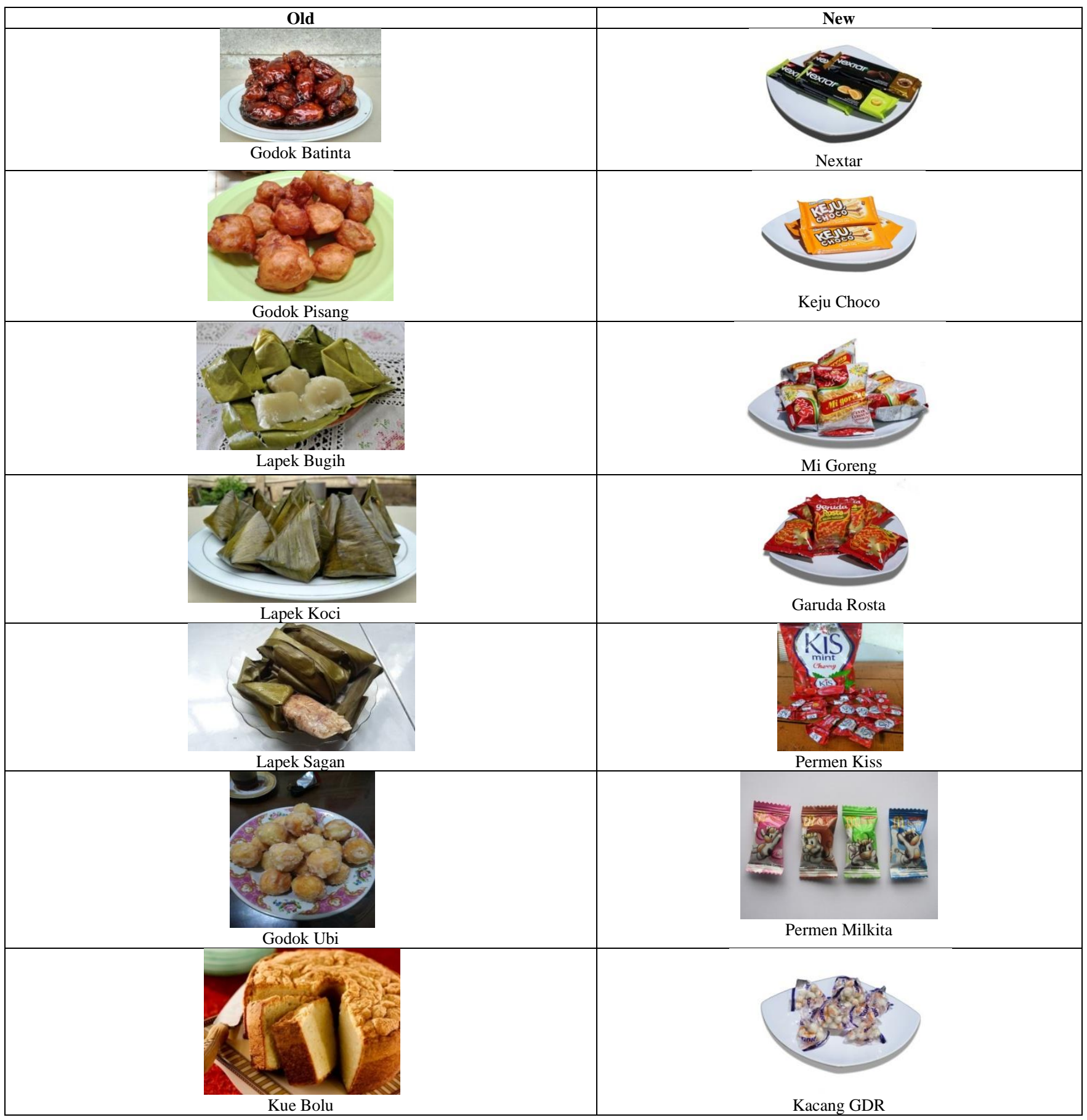

Seeing the changes mentioned above, the researchers saw that the changes that occurred in jamba and pinumkopi which were used as treats to the Prophet's birthday were caused by social changes and the development of science in the younger generation of the Pariaman people themselves. The same is the case with traditions in other areas such as the customs of digging onions in Palembang because people in modern times like this people no longer want to wear customs from traditional times used by parents at that time and people prefer activities that are modern like today which according to them prefers practical compared to the traditional era at that time [17]. In terms of according to [18], the function of Tradition is 1) Hereditary policies in which there is an awareness of the beliefs, norms and values currently held; 2) Provides legitimacy to existing views of life, beliefs, institutions and regulations; and 3) provide a convincing symbol of collective identity, strengthen primordial identity, towards the nation, community and group. However, [18] also explains that tradition can change when one establishes certain fragments of the legacy of the past as traditions and traditions change when people pay special attention to certain fragments and ignore old fragments.

\section{CONCLUSION}

There were changes in jamba and pinumkopi in the tradition of the Prophet Muhammad SAW's birthday in Pariaman due to social changes.

Changes in shape in Jamba and pinumkopi do not change

Published By:

Blue Eyes Intelligence Engineering and Sciences Publication

104 (c) Copyright: All rights reserved.

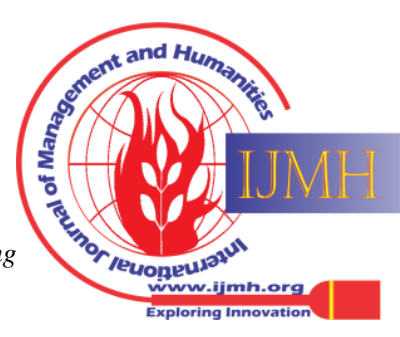


function and meaning. The Alteration occurs not because of changes in population, employment or urbanization but purely due to social changes and developments in science and modern civilization. Thus, the Minang proverb "cupak dialiah rang panggaleh jalan dialiah dekurang lalu" means that the norms and rules change because special newcomers to the Prophet's birthday, this proverb is more appropriate "cupak dialiah dek urang awak jalan dialiah dek urang paladang" means norms and rules change because of the community itself.

\section{REFERENCES}

1. D. K Marjanto. Pewarisan Nilai Budaya melalui Pranata Pendidikan Adat dalam Rangka Mendukung Program Penguatan Pendidikan Karakter (Ppk). Patanjala, 11(2), 2019, 291882.

2. L. Sumartono. Perlakuan Pengakuan Pendapatan dan Beban Pada PT Wijaya Karya (Persero), Tbk. dan Entitas Anak Terhadap Kewajaran Penyajian Laporan Laba Rugi Berdasarkan PSAK No. 23 Revisi 2010. FIN-ACC (Finance Accounting), 1(9). 2017.

3. B. Bungin Cet 4. Penelitian Kualitatif: Komunikasi, Ekonomi, Kebijakan Publik, dan Ilmu Sosial Lainnya. Jakarta: Elex Media. 2010

4. Koentjaraningrat. Beberapa Pokok Antropologi Sosial. Jakarta: Dian Rakyat.1992.

5. L.J. Maleong. Metodologi Penelitian Kualitatif. Bandung: PT. Remaja Rosdakarya. Pemerintah Republik Indonesia. 2010.

6. B. Butterworth. Developmental dyscalculia. Child neuropsychology: Concepts, theory, and practice, 2008. 357-374.

7. B. Rudito, M. Famiola. (2013). CSR (Corporate Social Responsibility)

8. P. Anggorowati, S. Sarmini. Pelaksanaan Gotong-Royong di Era Global (Studi Kasus di Desa Balun Kecamatan Turi Kabupaten Lamongan). Kajian Moral dan Kewarganegaraan, 1(3), 2015. 39-53.

9. E. D. Lewis. Langkah-langkah Menuju Sebuah Pemahaman tentang Budaya. 2015.

10. Haryatmoko. Habitus dan Kapital dalam Strategi Kekuasaan : Teori Strukturasi Pierre Bourdieu dengan Orientasi Budaya. Makalah Workshop di Paska - Sarjana ISI Yogyakarta. 2013

11. S. D. Faizzati. Tradisi bajapuik dan uang hilang pada perkawinan adat masyarakat perantauan Padang Pariaman di Kota Malang dalam tinjauan 'urf (Doctoral dissertation, Universitas Islam Negeri Maulana Malik Ibrahim). 2015

12. J. Ranjabar. Sistem Sosial Budaya Indonesia Suatu Pengantar. Bandung: Alfabeta. 2014

13. Suryanti. Menggali Makna Upacara Maulid Nabi di Padang Pariaman Sumatera Barat. Panggung, 22(4). 2012

14. E. M. Setiadi. Ilmu Sosial dan Budaya Dasar. Jakarta: Kencana Prenada Media Group. 2007

15. B. Raho. Sosiologi. Maumere: Ledalero. 2016

16. Soekanto. Sosiologi Suatu Pengantar. Jakarta: PT Raja Grafindo Persada. 2014

17. M. Kurniawan, E. F. Emil, Kurnisar. Faktor Yang Menyebabkan Perubahan Adat Istiadat "Ngocek Bawang" Di Kelurahan Indralaya Mulya Kec. Indralaya Kab. Ogan Ilir. Bhinneka Tunggal Ika, 6(1), 2019

18. P. Sztompka. Sosiologi Perubahan Sosial. Jakarta Pranada media. 2004

\section{AUTHORS PROFILE}

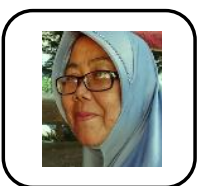

Jupriani is a Doctoral Student of Education Sciences, and Lecturer of Department of Fine Arts, Universitas Negeri Padang - Indonesia.

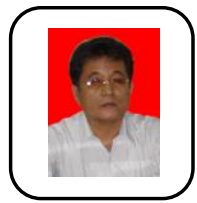

Mukhaiyar is a Senior lecturers/professor of Education Sciences, Universitas Negeri Padang Indonesia.

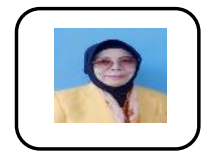

Agusti Efi is a Senior lecturers/professor of Education Sciences, Universitas Negeri Padang - Indonesia. 